\title{
PEMBEDAAN TOKOH DALAM KARYA SASTRA
}

\author{
Nofitasari \\ Fakultas Sastra, Universitas Muslim Indonesia \\ Jalan Urip Sumoharjo KM 5, Makassar \\ nofitasari1120@gmail.com
}

\begin{abstract}
Abstrak: Karakter tokoh dalam sebuah cerita novel dapat diketahui melalui peran yang disandang dengan ciri sifat masing-masing tokoh. Karakter tokoh diambil dari karakter manusia secara umum dalam kehidupan. Watak tokoh terbagi dua yaitu watak yang baik dan watak yang buruk yang dikenal dengan karakter protagonis dan karakter antagonis. Watak tersebut kemudian disederhanakan menjadi berbagai karakter. Karakter baik atau protagonist dikelompokkan menjadi beberapa karakter seperti karakter adil, berani, jujur, penyayang, rajin, dan amanah, sedangkan watak antagonis (karakter buruk) adalah sebaliknya seperti karakter curang, karakter penakut, pembenci, pemalas dan hianat. Tokoh adalah individu ciptaan/rekaan pengarang yang mengalami peristiwa-peristiwa atau lakukan dalam berbagai peristiwa cerita. Pembedaan tokoh terdiri dari tokoh utama dan tokoh tambahan, tokoh protagonist dan tokoh antagonis, tokoh sederhana dan tokoh bulat, tokoh statis dan tokoh berkembang serta tokoh tipikal dan tokoh netral.
\end{abstract}

Kata Kunci: Pembedaan tokoh, karya sastra

\section{PENDAHULUAN}

Fiksi merupakan salah satu bentuk karya yang kreatif, maka bagaimana pengarang mewujudkan dan mengembangkan tokoh-tokoh ceritanya pun tidak lepas dari kebebasan kreatifitasnya. Fiksi mengandung dan menawarkan model kehidupan seperti yang disikapi dan dialami oleh tokoh-tokoh cerita sesuai dengan pandangan pengarang terhadap kehidupan itu sendiri. Oleh karenanya pengarang sengaja menciptakan dunia dalam fiksi, ia mempunyai kebebasan penuh untuk menampilkan tokoh-tokoh cerita sesuai dengan seleranya, dan permasalahan apapun yang dihadapinya, singkatnya pengarang berhak menampilkan tokoh, siapaun dia orangnya walau hal itu berbeda dengan dunianya sendiri di dunia nyata.
Tokoh cerita mempunyai tempat strategis sebagai pembawa dan penyampai pesan, amanat, moral ataupun sesuatu yang sengaja ingin disampaikan kepada pembaca. Keadaan ini juga sering berakibat kurang menguntungkan para tokoh cerita itu sendiri dilihat dari segi kewajarannya dalam segi bersikap dan bertindak. Tidak tokoh-tokoh cerita dipaksa dan diperalat sebagai pembawa pesan sehingga tokoh cerita dan sebagai pribada kurang berkembang kurang berkembang. Secara ekstren boleh dikatakan, mereka hanya sebagai robot yang selalu tunduk kepada kemauan pengarang dan kepribadiannya sendiri.

Fiksi mengandung dan menawarkan model seperti yang disikapi dan dialami tokoh-tokoh cerita sesuai dengan pandangan pengarang terhadap kehidupan itu sendiri. Pengarang bebas 
untuk menampilkan tokoh-tokoh dalam cerita sesuai dengan dunianya. Dalam penulisan sebuah cerita, pengarang tidak akan lepas dari apa yang disebut penokohan dan karakteristik.

Dalam sebuah novel, suatu cerita tidak hanya bercerita mengenai ruang dan waktu tertentu yang kosong. Cerita tersebut semata-mata tidak bercerita mengenai suatu lingkungan sosial cultular dalam pengertian yang umum dan abstrak. Sebuah cerita bercerita mengenai kehidupan manusia yang menyatakan diri dalam seluk-beluk persoalan yang dialami seorang tokoh maupun persoalan yang berkembang di sekita kehidupan tokoh tertentu secara spesifik. Cerita itu membuat persoalan kehidupan manusia yang umum dan abstrak tidak hanya menjadi sebuah dunia pemahaman, melainkan sebagai dunia pengalaman dan penghayatan.

\section{PEMBAHASAN}

Tokoh-tokoh cerita dalam sebuah cerita fiksi dapat dibedakan ke dalam beberapa jenis penamaan berdasarkan sudut pandang mana penamaan itu dilakukan. Berdasarkan perbedaan sudut pandang dan tinjauan tertentu, seorang tokoh dapat dikategorikan ke dalam beberapa jenis sekaligus, misalnya sebagai tokoh utama-pratagonis-berkembangtipikal.

Karya sastra dapat membentuk kepribadian karena didalamnya memuat amanat tentang moral, mengembangkan imajinasi dan kreativitas siswa. Selanjutnya, karya sastra yang baik memiliki beberapa kriteria, salah satunya adalah memberikan pembelajaran kepada pembacanya.

Berbicara tentang tokoh atau penokohan, setidaknya ada beberapa istilah yang sering dipertukarkan antara satu dengan yang lain. Misalnya, ada sebutan tokoh, da nada pula sebutan penokohan, watak dan perwatakan atau karakter dan karakterisasi. Biasanya tokoh dalam fiksi naratif jumlahnya tidak banyak, apalagi yang berstatus sebagai tokoh utama. Lebihlebih dalam cerita pendek, tokoh-tokoh yang muncul jumlahnya terbatas sekali. Tidak hanya jumlah tokoh-tokoh yang terbatas, data-data jati diri tokoh, khususnya yang berkaitan dengan perwatakan pun demikian, sehingga pembaca harus berkonstruksi sendiri gambaran yang lebih lengkap tentang tokoh itu.

\section{Tokoh Utama dan Tokoh Tambahan}

Pembedaan tokoh ke dalam kategori ini didasarkan pada peran dan pentingnya seorang tokoh dalam cerita fiksi secara keseluruhan. Membaca sebuah novel, biasanya, kita akan dihadapkan pada sejumlah tokoh yang di hadirkan di dalamnya. Namun, dalam kaitannya dengan keseluruhan cerita, peranan masing-masing tokoh tersebut tidak sama. Dilihat dari segi peranan atau tingkat pentingnya tokoh dalam sebuah cerita tersebut, ada tokoh yang tergolong penting dan ditampilkan terus-menerus sehingga terasa mendominasi sebagian besar cerita. Tokoh yang disebut pertama adalah tokoh utama cerita (central character), sedangkan yang kedua adalah tokoh tambahan atau tokoh peripheral (peripheral character).

Tokoh utama adalah tokoh yang diutamakan penceritaannya dan yang paling babnyak diceritakan, baik sebagai pelaku kejadian maupun yang dikenai kejadian. Berkaitan dengan tokoh utama, secara rinci Sudjiman (1998:17-20) menyebutkan kriteria dalam identifikasi 
tokoh utama, yaitu (1) intensitas keterlibatan tokoh dalam peristiwa yang membangun cerita; (2) frekuensi hubungan dengan tokoh lain; (3) judul cerita seringkali mengungkapkan tokoh utama; (4) panjang waktu untuk menemukan tokoh utama.

Tokoh utama seringkali muncul dalam setiap kejadian dan dapat ditemui hampir dalam setiap halaman buku cerita yang bersangkutan. Selain itu, tokoh ini tergolong penting karena diceritakan terus menerus sehingga cenderung mendominasi sebagian besar ceria. Tokoh utama dalam sebuah novel bisa saja lebih dari satu orang, walau kadar keutamaannya tak selalu sama. Kadar keutamaan yang dimaksud tergantung pada dominasi tokoh, banyaknya penceritaan, dan pengaruhnya dalam perkembangan plot secara keseluruhan.

Pada novel-novel yang lain, tokoh utama tidak muncul dalam setiap kejadian, atau tidak langsung ditunjuk dalam setiap bab, namun ternyata dalam kejadian atau bab tersebut tetap erat berkaitan, atau dapat dikaitkan, dengan tokoh utama. Dalam novel Burung-burung Manyar, misalnya terdapat lima bab $(4,9,11,13$, dan 14) dari ke-22 yang ada yang tidak menghadirkan tokoh utama cerita, Setadewa. Namun, dari ke-5 bab tersebut dua di antaranya (4 dan 13) erat kaitan dengan tokoh Satedewa, yang antara lain berisi pembicaraan tentangnya, sedang bab 3 yang lain $(9,11$, dan 13) juga dapat dikaitkan tokoh dengannya walaupun secara tidak langsung dalam hubungan sebab-akibat.

Karena tokoh utama paling banyak diceritakan dan selalu berhubungan dengan tokoh-tokoh lain, ia sangat menentukan perkembangan plot cerita secara keseluruhan. Ia selalu hadir sebagai pelaku, atau yang dikenai kejadian dan konflik, penting yang mempengaruhi perkembangan plot. Plot utama sebenarnya tidak lain adalah cerita tentang tokoh utama, bahkan kehadiran plot-plot lain atau sub-subplot lazimnya berfungsi memperkuat eksistensi tokoh utama itu juga.

Tokoh tambahan adalah tokoh yang hanya dimunculkan sekali atau beberapa kali dalam cerita dan itu pun dalam porsi penceritaan yang relatif singkat (Nurgiantoro, 1995:76). Artinya tokoh tambahan ini jarang sekali diceritakan oleh penulis. Kemunculan tokoh tambahan dalam keseluruhan cerita cenderung sedikit, tak dipentingkan, dan kehadirannya hanya jika ada keterkaitannya dengan tokoh utama. Bukan hanya tokoh utama yang mampu mempengaruhi perkembangan plot walaupun tidak banyak.

\section{Tokoh Protagonis dan Tokoh Antagonis}

Tokoh protagonist merupakan tokoh yang dikagumi, seperti tokoh hero, yakni tokoh yang merupakan pengejawantahan norma-norma dan nilainilai yang ideal bagi pembaca. Tokoh protagonist merupakan tokoh yang membawa misi kebenaran dan kebaikan untuk menciptakan situasi kehidupan masyarakat yang damai, aman, dan sejahtera (Hariyanto 2000:10). Berdasarkan pernyataan di atas dapat dikatakan bahwa tokoh protagonis merupakan tokoh yang dikagumi oleh pembaca. Namun, cita-cita tokoh protagonis ini tidak selalu mulus karena adanya perlawanan dari tokoh antagonis.

Tokoh protagonis menampilkan sesuatu yang sesuai dengan pandangan kita, harapan-harapan kita, harapanharapan pembaca. Maka, kita sering mengenalinya sebagai memiliki kesamaan 
dengan kita, permasalahan yang dihadapinya seolah-olah juga sebagai permasalahan kita, demikian pula halnya dalam menyikapinya. Sebuah fiksi harus mengandung konflik, ketegangan, khususnya konflik dan ketegangan yang dialami oleh tokoh protagonis.

Tokoh antagonis merupakan tokoh yang menyebabkan terjadinya konflik. Tokoh antagonis dapat pula disebut sebagai tokoh yang beroposisi dengan protagonist, secara langsung ataupun tidak langsung, bersifat fisik ataupun batin (Altenberd dan Lewis dalam Nurgiantora, 1995: 178-9). Oleh karena itu, tokoh ini biasanya digambarkan sebagai tokoh yang berwatak buruk dan negatif, seperti pendendam, culas, pembohong, mengahalalkan segala cara, sombong, iri, suka pamer dan ambisius. Meskipun demikian, ada juga tokoh-tokoh antagonis yang bercampur dengan sifat-sifat yang baik beroposisi dengan tokoh protagonis.

Secara umum dapat dikatakan bahwa kehadiran tokoh antagonis penting dalam sebuah cerita fiksi, khususnya fiksi yang mengangkat masalah pertentangan antara dua kepentingan, seperti baik-buruk, baik-jahat, benar-salah, dan lain-lain yang sejenis. Tokoh antagonislah yang menyebabkan timbulnya konflik dan ketegangan sehingga cerita menjadi menarik. Konflik yang dialami oleh tokoh protagonis tidak hanya yang harus disebabkan oleh tokoh antagonis (beberapa orang) individu yang dapat ditunjuk secara jelas. Ia dapat disebabkan oleh hal-hal lain yang di luar individualitas seseorang, bencana alam, kecelakaan, lingkungan alam dan sosial, aturan-aturan sosial, nilainilai moral, kekuasaan yang lebih tinggi, sebagainya.

\section{Tokoh Sederhana dan Tokoh Bulat}

Pembedaan tokoh sederhana dan tokoh bulat dilakukan berdasarkan perwatakannya. Dengan mengkaji dan mendalami perwatakan para tokoh dalam suatu cerita fiksi, kita kita dapat membedakan tokoh-tokoh yang ada ke dalam kategori tokoh sederhana (simple atau flat character) dan tokoh kompleks atau tokoh bulat (complex atau round character).

Tokoh yang mempunyai karakter sederhana adalah tokoh yang hanya mempunyai karakter seragam atau tunggal (Aminuddin 1984:9). Artinya, tokoh ini hanya memiliki satu watak tertentu saja. Tokoh jenis ini merupakan tokoh yang tidak memberikan efek kejutan bagi para pembaca karena tidak semua sisi kehidupannya diungkapkan. Sifat dan tingkah laku tersebut mendapat tekanan terus menerus dalam cerita. Dengan demikian, pembaca akan lebih mudah memahami watak serta tingkah laku yang dimiliki oleh tokoh sederhana. Tokoh sederhana dalam bentuknya yang asli, adalah tokoh yang hanya memiliki suatu kualitas pribadi tertentu, satu sifat watak tertentu saja. Sebagai seorang tokoh manusia, ia tidak diungkap berbagai kemungkinan sisi kehidupannya. Ia tidak memiliki sifat dan tingkah laku yang dapat memberikan efek kejutan bagi pembaca. Sifat, sikap, dan tingkah laku seorang tokoh sederhana bersifat datar, monoton, hanya mencerminkan satu watak tertentu. Watak yang telah pasti itulah yang mendapat penekanan dan terus-menerus terlihat dalam cerita fiksi yang bersangkutan.

Tokoh sederhana dapat saja melakukan berbagai tindakan, namun semua tindakannya itu akan dapat dikembalikan pada perwatakan yang 
dimiliki dan yang telah diformulakan itu. Dengan demikian, pembaca akan dengan mudah memahami watak dan tingkah laku tokoh sederhana. Ia mudah dikenal dan dipahami, lebih familiar dan cenderung sterotip. Tokoh sebuah cerita fiksi yang bersifat familiar sudah biasa atau yang stereotip memang dapat digolongkan sebagai tokoh-tokoh tang berwatak sederhana (Kenny, 1966:28).

Tokoh bulat ialah tokoh yang memiliki sifat dan tingkah laku yang kompleks dan kadang-kadang dapat bertentangan dan sulit diduga (Forster, 1970:75). Tokoh bulat adalah tokoh yang memiliki dan diungkap berbagai kemungkinan sisi kehidupannya, sisi kepribadian dan jati dirinya. Ia dapat saja memiliki watak tertentu yang dapat diformulasikan, namun iapun dapat pula menampilkan watak dan tingkah laku yang bermacam-macam, bahkan mungkin seperti bertentangan dan sulit diduga. Perwatakannya pun pada umumnya sulit dideskripsikan secara tepat (Nurgiyantoro, 1995:183). Dengan demikian, tokoh bulat lebih sulit dipahami, tingkah lakunya sering tidak terduga dan memberikan efek kejutan bagi pembaca. Tokoh bulat juga cenderung menyerupai kehidupan manusia yang sesungguhnya. Oleh karena itu, perwatakanpun pada umumnya sulit dideskripsikan secara tepat. Dibandingkan dengan tokoh sederhana, tokoh bulat lebih menyerupai kehidupan manusia yang sesungguhnya karena di samping memiliki berbagai kemungkinan sikap dan tindakan, ia juga sering memberikan kejutan (Abrams, 1999:33).

Tokoh kompleks, dengan demikian, lebih sulit dipahami dan terasa kurang familiar karena yang ditampilkan adalah tokoh-tokoh yang kurang akrab dan kurang dikenal sebelumnya, tingkah lakunya sering tidak terduga, dan tidak jarang memberikan efek kejutan kepada pembaca.

Tingkat kompleksitas. Pembedaan tokoh cerita ke dalam kategori tokoh sederhana dan kompleks sebenarnya lebih bersifat teoretis sebab pada kenyataannya tidak ada ciri perbedaan yang dipilah di antara keduanya. Perlu ditegaskan bahwa pengertian tokoh sederhana dan kompleks tersebut tidak bersifat pengontrasan atau dalam pengertian berkebalikan. Artinya, tokoh sederhana bukan sebagai kebalikan atau dalam pertentangannya dengan tokoh bulat. Perbedaan antara tokoh sederhana dan tokoh kompleks itu lebih bersifat penggradasian, berdasarkan tingkat kompleks watak yang dimiliki para tokoh. Jadi, keadaan itu dapat berwujud: sederhana, agak kompleks, lebih kompleks, kompleks, dan kompleks. Jadi, ia lebih merupakan deskripsi tingkat intensitas komplesitas perwatakan seorang tokoh itu.

Fungsi. Sebagaimana dikemukakan di atas, tokoh sederhana tampak kurang sesuai dengan realitas kehidupan sebab tidak ada seorang pun yang hanya memiliki satu sifat-watak tertentu. Manusia adalah makhluk yang kompleks, memiliki sifat watak yang tak terduga (bagi manusia lain), dan tidak jarang bersikap dan bertindak secara mengejutkan. Dengan demikian, tokoh kompleks lebih mencerminkan realitas kehidupan manusia. Tokoh bulat dalam sebuah novel biasanya lebih menarik daripada tokoh sederhana. Namun, hal itu tidak perlu diartikan bahwa tokoh sederhana menjadi tidak menarik, tidak perlu ada, kurang baik, atau bahkan gagal.

\section{Tokoh Statis dan Tokoh Berkembang}

Tokoh statis ialah sifat tokoh yang tidak mengalami perkembangan 
disepanjang cerita meskipun dighadapkan pada kondisi dan situasi yang berbeda dan bertentangan. Menurut Altenbernd dan Lewis (dalam Nurgiyantoro, 1995:188) tokoh statis (static character) adalah tokoh cerita yang secara esensial tidak mengalami perubahan dan perkembangan perwatakan sebagai akibatnya adanya peristiwa-perisiwa yang terjadi. Dapat dikatakan bahwa tokoh semacam ini tidak terpengaruh oleh perubahan lingkungan sekitarnya yang terjadi akibat hubungan antra tokoh.

Tokoh ini merupakan pelaku dalam sastra sastra drama yang dalam keseluruhan drama tersebut sedikit sekali bahkan tidak berubah wataknya. Tokoh statis adalah tokoh yang datar dan sederhana. Karena ia tidak diungkap semua sisi kehidupannya sehingga dianggap kurang mencerminkan realitas kehidupan. Dalam tokoh statis dikenal tokoh tokoh hitam (tokoh jahat) dan tokoh putih (tokoh baik). Tokoh hitam adalah tokoh yang sikap, watak, dan tingkah lakunya jahat dari awal hingga akhir cerita. Begitupun sebaliknya, tokoh putih adalah tokoh yang selalu baik, tidak pernah berbuat sesuatu yang mempunyai cita buruk.

Tokoh berkembang (developing character) adalah pelaku dalam sastra drama yang dalam keseluruhan drama tersebut mengalami perubahan atau perkembangan watak. Tidak jauh berbeda dengan pernyataan diatas, tokoh berkembang juga diartikan sebagai tokoh cerita yang mengalami perubahan dan perkembangan perwatakan sejalan dengan perkembangan serta perubahan peristiwa dan plot yang dikisahkan. Menurut Nurgiyantoro (1995:188) tokoh berkembang secara aktif berinteraksi dalam lingkungannya, baik lingkungan sosial, alam, maupun yang lain, yang kesemuanya itu memengaruhi sikap watak dan tingkah lakunya. Jadi tokoh berkembang bisa saja mengalami perubahan yang senantiasa terjadi disebabkan oleh lingkungan disekitarnya.

\section{Tokoh Tipikal dan Tokoh Netral}

Tokoh tipikal (typical character) menurut Altenbernd dan Lewis (dalam Nurgiyantoro, 1995:190) adalah tokoh yang hanya sedikit ditampilkan keadaan individualisnya, dan lebih banyak ditonjolkan kualitas pekerjaan atau kebangsaannya, atau sesuatu yang lain yang bersifat mewakili. Tokoh tipikal merupakan penggambaran seseorang/ sekelompok orang yang terikat dalam sebuah lembaga, yang ada di dunia nyata. Pihak pembacalah yang akhirnya mampu menafsirkan sendiri berdasarkan pengetahuan dan pengalaman terhadap tokoh di dunia nyata dan tokoh di dunia fisik. Melalui penokohan tipikal pengarang memberikan reaksi/tanggapan, memperlihatkan sikapnya terhadap tokoh permasalahan serta sikap tokoh itu sendiri. Penggambaran itu tentu saja bersifat tidak langsung dan tidak menyeluruh dan justru pihak pembacalah yang menafsirkannya secara demikian berdasarkan pengetahuan, pengalaman, dan persepsinya terhadap tokoh di dunia nyata dan pemahamannya terhadap tokoh cerita di dunia fiksi.

Tokoh netral (netral character) adalah tokoh cerita yang bereksistensi demi cerita itu sendiri. Ia merupakan tokoh imajiner yang hanya hidup dan bereksistensi dalam dunia fiksi (Nurgiyantoro, 1995:191). Maka dapat dikatakan bahwa kehadiran tokoh netral hanya semata-mata demi cerita, bukan untuk mewakilkan sesuatu yang ada di dunia nyata. Pembaca akan kesulitan untuk menafsirkan karena kurangnya gambaran 
yang ada dalam kehidupan nyata. Ia hadir (atau dihadirkan) semata-mata demi cerita, atau bahkan dialah sebenarnya yang empunya cerita, pelaku cerita, dan yang diceritakan. Kehadirannya tidak berpretensi untuk mewakili atau menggambarkan sesuatu yang di luar dirinya, seseorang yang berasal dari dunia nyata. Atau paling tidak, pembaca mengalami kesulitan untuk menafsirkannya sebagai bersifat mewakili berhubung kurang ada unsur bukti pencerminan dari kenyataan di dunia nyata.

\section{Teknik Penulisan Tokoh}

Secara garis besar teknik penulisan tokoh dalam suatu karya meliputi pelukisan sifat, sikap, watak, tingkah laku, dan berbagai hal lain yang berhubungan dengan jati diri tokoh dapat dibedakan ke dalam dua cara atau teknik, antara lain:

1. Teknik ekspositori, biasa disebut sebagai teknik analisis. Dalam teknik ini pelukisan tokoh cerita dilakukan dengan memberikan deskripsi, uraian, atau penjelasan secara langsung (Nurgiyantoro 1995:195). Jadi, tokoh cerita dihadirkan oleh pengarang ke hadapan pembaca secara langsung dan disertai dengan deskripsi kediriannya secara lengkap, yang dapat beruba sikap, sifat, watak, perilaku, atau ciri fisiknya.

Deskripsi kedirian tokoh yang dilakukan secara langsung oleh pengarang akan berwujud penuturan yang bersifat deskriptif pula . pengarang menjelaskan kedirian tokoh dengan cepat dan singkat. Dengan demikian, pembaca kurang didorong untuk berperan dalam memberikan tanggapannya terhadap tokoh. Selain itu, penuturan dalam teknik ini bersifat mekanis dan kurang dialamai. Maksudnya, dalam realita yang ada, tidak ada orang yang mendeskripsikan kedirian seorang secara lengkap. Misalkan, menerangkan kepada orang lain tentang watak kita secara rinci kepada orang lain. Namun, perlu diingat bahwa tak selamanya teknik analitis tidak cocok digunakan untuk menjelaskan kedirian seseorang. Tekni ekspositori bisa digunakan dengan efektif apabila penggunaannya tepat sesuai porsinya.

2. Teknik dramatik, adalah teknik reaksi tokoh. Minderop (Mulyadi, 20017:37) menyebutkan teknik dramatik reaksi tokoh ini dengan sebutan karakterisasi kualitas mental dan perilaku tokoh. Ia juga menyebutkan bahwa teknik dramatik cakapan dengan karakterisasi tokoh melalui dialog. Pengarang membiarkan pembaca untuk menciptakan persepsinya tentang kedirian tokoh melalui tindakan/tingkah laku, aktivitas yang dilakukan, juga melalui peristiwa yang dialami tokoh. Di samping itu, pengarang mendeskripsikan kedirian tokoh secara sepotong-sepotong dan tidak sekaligus dan akan menjadi lengkap apabila pembaca menyelesaikan sebagian besar cerita. Sehingga pembaca dituntut untuk dapat menafsirkan dan memahami sendiri kedirian tokoh. Namun, buruknya adalah pembaca berpeluang besar untuk mengalami salah paham, salah penilaian, salah tafsir, atau malah tidak paham.

Teknik dramatik sifatnya lebih sesuai dengan situasi kehidupan nyata. Contohnya, ketika kita mengenal seseorang yang baru, kita tidak akan langsung menanyakan sifat orang tersebut, tetapi kita akan mencoba mengamati, memahami sifat-sifat orang itu melalui tingkah lakunya, kata-katanya, sikapnya, serta pandangan-pandangannya dalam kehidupan sehari-hari.

Wujud Penggambaran Teknik

Dramatik. Penampilan tokoh secara 
dramatic dapat dilakukan lewat sejumlah teknik. Dalam sebuah cerita fiksi, biasanya pengarang mempergunakan berbagai teknik itu secara bergantian dan saling mengisi walau ada perbedaan frekuensi penggunaan masing-masing teknik. Mungkin saja ada satu dua teknik yang lebih sering dipergunakan daripada teknikteknik yang lain tergantung pada selera atau kesukaan masing-masing pengarang. Tentu saja hal itu tidak lepas dari tujuan estetis dan keutuhan cerita secara keseluruhan. Berbagai teknik yang dimaksud sebagian di antaranya dikemukakan di bawah ini dengan disertai contoh seperlunya.

\section{a. Teknik Cakapan}

Percakapan yang dilakukan oleh (baca: diterapkan pada) tokoh-tokoh cerita biasanya juga dimaksudkan untuk menggambarkan sifat-sifat tokoh yang bersangkutan. Bentuk percakapan dalam sebuah cerita fiksi, khususnya novel, umumnya cukup banyak, baik percakapan yang pendek maupun yang (agak) panjang.

\section{b. Teknik Tingkah Laku}

Jika teknik cakapan dimaksudkan untuk menunjukkan tingkah laku verbal yang verbal berwujud kata-kata dan atau dialog para tokoh, teknik tingkah laku menunjuk pada kata tindakan nonverbal, fisik, apa yang dilakukan orang dalam wujud tindakan dan tingkah laku, dalam banyak dapat dipandang sebagai menunjukkan reaksi, tanggapan, sifat, dan sikap, yang mencerminkan perwatakannya.

\section{c. Teknik Pikiran dan Perasaan}

Teknik pikiran dan perasaan dapat ditemukan dalam teknik cakapan dan tingkah laku. Artinya, penuturan itu sekaligus untuk menggambarkan pikiran dan perasaan tokoh. Keadaan itu memang tidak mungkin dipilahkan secara tegas. Hanya, teknik pikiran dan perasaan dapat juga berupa sesuatu yang belum tentu dilakukan secara konkret dalam bentuk tindakan dan kata-kata, dan hal ini dapat terjadi sebaliknya.

\section{d. Teknik Arus Kesadaran}

Teknik arus kesadaran (stream of consciousness) berkaitan erat dengan teknik pemikiran dan perasaan. Keduanya tidak dapat dibedakan secara pilah, bahkan mungkin dianggap sama karena memang sama-sama menggambarkan tingkah laku batin seorang tokoh. Dewasa ini dalam fiksi modern teknik arus kesadaran banyak dipergunakan untuk melukiskan sifat-sifat kedirian tokoh. Arus kesadaran merupakan sebuah teknik narasi yang berusaha menangkap pandangan dan aliran proses mental tokoh, di mana tanggapan indera bercampur dengan kesadaran dan ketaksadaran pikiran, perasaan, ingatan, harapan, dan asosiasi-asosiasi acak (Abrams, 1999:298).

\section{e. Teknik Reaksi Tokoh}

Teknik reaksi tokoh dimaksudkan sebagai rekasi tokoh terhadap suatu kejadian, masalah, keadaan, kata, dan sikap-tingkah-laku orang lain, dan sebagainya yang berupa "rangsang"dari luar diri tokoh yang bersangkutan. Bagaimana reaksi tokoh terhadap hal-hal tersebut dapat dipandang sebagai suatu bentuk penampilan yang mencerminkan sifat-sifat kediriannya.

\section{f. Teknik Reaksi Tokoh Lain}

Reaksi tokoh(-tokoh) lain dimaksudkan sebagai reaksi yang diberikan oleh tokoh lain terhadap tokoh utama, atau tokoh yang dipelajari 
kediriannya, yang berupa pandangan, pendapat, sikap, komentar, dan lain-lain.

\section{g. Teknik Pelukisan Latar}

Pelukisan suasana latar dan dapat lebih mengintensifkan sifat kedirian tokoh seperti yang telah diungkapkan dengan berbagai teknik yang lain. Keadaan latar tentu adakalanya dapat menimbulkan kesan yang tertentu pula dipihak pembaca. Misalnya, suasana rumah yang bersih, teratur, rapi, tidak ada barang yang mengganggu pandangan, akan menimbulkan kesan bahwa pemilik rumah itu sebagai orang yang cinta kebersihan, lingkungan, teliti, teratur, dan sebagainya yang sejenis.

\section{h. Teknik Pelukisan Fisik}

Pelukisan keadaan fisik seseorang sering berkaitan dengan keadaan kejiwaanna, atau paling tidak, pengarang sengaja mencari dan memperhubungkan adanya keterkaitan itu. Misalnya, bibir tipis menyaran pada sifat ceriwis dan bawel, rambut lurus menyaran pada sifat tidak mau mengalah, pandangan mata tajam, hidung agak mendongak, bibir yang bagaimana, dan lain-lain yang dapat menyaran pada sifat tertentu.

\section{PENUTUP}

Tokoh adalah pelaku yang memerangkan karakter cerita dalam sebuah fiksi. Karakter dapat berarti "pelaku cerita" dan dapat pula berarti perwatakan. Karakterisasi memiliki makna sebagai suatu usaha untuk menampilkan karakter atau watak dari tokoh. Berdasarkan perbedaan sudut pandang dan tinjauan, seorang tokoh dapat dikategorikan ke dalam beberapa jenis penamaan, antara lain tokoh utama dan tokoh tambahan, tokoh protagonist dan tokoh antagonis, tokoh sederhana dan tokoh bulat, tokoh statis dan tokoh berkembang, serta tokoh tipikal dan tokoh netral.

\section{DAFTAR PUSTAKA}

Mansyur, Umar. 2016. Pemanfaatan Nilai Kejujuran dalam Cerpen sebagai Bahan Ajar Cerpen Berbasis Pendidikan Karakter. In Mengais Karakter dalam Sastra: HIKSI Makassar (pp. 330-339). http://doi.org/10.17605/OSF.IO/Z4T3Y

Mansyur, Umar. 2018. Kiat dan Teknik Penulisan Skripsi bagi Mahasiswa. INA-Rxiv. https://doi.org/10.31227/0sf.oi/juds7

Muliadi, 2017. Buku Ajar Telaah Prosa: Sebuah Terapan. Makassar: De La Macca.

Nektariti. 2013. https://www.rumpunnektar.com/2013/1/perbedaan_tokoh_dengan_ penokohan.html?m=1 diakses pada tanggal 20 Oktober 2018.

Nurgiyantoro, Burhan. 2015 . Teori Pengajaran Fiksi. Yogyakarta: Gadjah Mada University Press.

Prameswari, Arsya. 2017.https://www.academia.edu/35640183/MAKALAH_KAJIAN_ PROSA_FIKSI_PENOKOHAN_DAN_KARAKTERISASI_KELOMPOK_4 diakses pada tanggal 20 Oktober 2018.

Warnati. 2014. https://warnati094.blogspot.com/2014/06/tokoh-dan-penokohan-telaahprosa.html? $\mathrm{m}=$. diakses pada tanggal 20 Oktober 2018.

Warsiman. 2013. Membangun Pemahaman Terhadap Karya Sastra Berbentuk Fiksi (Telaah Sifat dan Ragam Fiksi Naratif). Jurnal Thaqafiyyat, Vol. 14(1), 180-183. 